DOI: $10.21554 / \mathrm{hrr} .091801$

\title{
INCLUSION AND d/DEAF AND HARD OF HEARING STUDENTS: A QUALITATIVE META-ANALYSIS
}

\section{Khalid Alasim ${ }^{1}$ \\ Peter V. Paul ${ }^{2}$}

${ }^{1}$ Department of Special Education, Prince Sattam bin Abdulaziz University

${ }^{2}$ Department of Educational Studies, The Ohio State University
Original scientific paper

Received: 22.06 .2018 .

Accepted: 29.07.2018.

\begin{abstract}
This study investigated the prominent perspectives on the effects of inclusion on d/Deaf and hard of hearing $(d / D h h)$ students. A systematic search of databases and journals was conducted. The researchers identified 23 studies that met the inclusion criteria, and other articles were analyzed to support the interpretations and provide suggestions for the improvement of inclusion. Inclusion of d/Dhh students in general education classrooms is controversial because of the students' unique language and communication needs. In addition, there are contradictory findings regarding the effects of inclusion on academic achievement and social development. These inconsistent findings were primarily due to the use of different research methodologies, different measurements and tests, and the diverse experiences of the home and school environments. Based on the findings of this study, recommendations for further research are suggested.
\end{abstract}

Keywords: Inclusion, Academic Achievement, Perspective, Social Interaction

INCLUSION AND D/DEAF AND HARD OF HEARING STUDENTS: A QUALITATIVE META-ANALYSIS

The number of $d /$ Deaf and hard of hearing (d/Dhh) students who are educated in general education classrooms has increased in several countries (EriksBrophy \& Whittingham, 2013). In the United States (USA), for example, most d/Dhh students are educated in general education classrooms with typical (hearing) peers (e.g., Johnson, 2013; Salend, 2001). Information from the U.S. Department of Education (2013) indicated that about $19.4 \%$ of students spend $40 \%$ to $70 \%$ of their day in general education classrooms whereas $61.8 \%$ spend $80 \%$ or more of their day in general education classrooms. In addition, about $13.8 \%$ of students spend less than $40 \%$ of the day in general education classrooms, and about $2.9 \%$ are in separate schools for students with disabilities. About $2.1 \%$ are educated in separate residential facilities or regular private schools, such as homebound/hospital placements, and correctional facilities.

Similarly, the majority of d/Dhh students in England receive their education in general education classrooms with typical peers (Power, 2002).

\footnotetext{
$\overline{{ }^{1} \text { Correspondence to: }}$

Khalid Nasser Alasim, PhD, Prince Sattam bin Abdulaziz University, Department of Special Education

E-mail: k.alasim@psau.edu.sa

Peter V. Paul, PhD, The Ohio State University, Department of Educational Studies

E-mail: Paul.3@osu.edu
} 
According to Eatough (2000), in 1998, most students with moderate to profound hearing loss were educated in general public schools, and only $20 \%$ were educated in special schools for $\mathrm{d} / \mathrm{Dhh}$ students. At present, about $85 \%$ of $\mathrm{d} / \mathrm{Dhh}$ students are educated in mainstream schools in England whereas 3\% receive their education in special schools for $\mathrm{d} / \mathrm{Dhh}$ children and $12 \%$ in special schools not specifically for $\mathrm{d} / \mathrm{Dhh}$ children (Consortium for Research in Deaf Education, 2017).

It has been asserted that the number of students in general education classrooms will continue to grow in light of legislation that supports inclusion in several countries, including developing countries. In addition, researchers predict an increase in the inclusion of $\mathrm{d} / \mathrm{Dhh}$ students due to the effectiveness of early identification, early amplification, and early intervention programs (Antia, Jones, Reed, \& Kreimeyer, 2009; Standley, 2005; also, see discussion in Wang \& Engler, 2010). The expected increase of students who are educated in general education classrooms is attributed to factors such as financial pressures, parental expectations, and technological developments (Angelides \& Aravi, 2007; Antia et al., 2009).

Given the increase in the number of $\mathrm{d} / \mathrm{Dhh}$ students in general education classrooms, several questions that address a number of important aspects of the inclusion of $\mathrm{d} / \mathrm{Dhh}$ students have been raised (e.g., Antia, Jones, Luckner, Kreimeyer, \& Reed, 2011). For example: Does inclusion positively affect the academic and social development of $\mathrm{d} /$ Dhh students? Can these students access the general education curriculum? Are there barriers that inhibit the inclusion of students? Are general education classroom teachers qualified to teach $\mathrm{d} / \mathrm{Dhh}$ students in their classrooms? If so, are they willing to collaborate with special education teachers of d/Dhh students? In general, the answers to these questions may be influenced by quality indicators associated with research such as demography, the nature of the researchable questions, validity of instruments, research designs, and so on (e.g., see discussions of research and deafness in Easterbrooks, 2017; Luckner, 2017; Mitchell, 2017; Paul \& Wang, 2017). Other factors include the nature of the constructs being measured (e.g., language and literacy development) and the sociocultural contexts of schools (e.g., teacher-student interactions; teacher competency).

In this article, we synthesize a selection of primary (i.e., original, empirical) and secondary (i.e., research reviews) investigations to address the following three questions:
1. What are the prominent perspectives on the effects of inclusion for $\mathrm{d} /$ Dhh students?

2. Are the research findings on the effects of inclusion consistent or inconsistent?

3. What are the salient suggestions to enhance the inclusion of $\mathrm{d} / \mathrm{Dhh}$ students?

Based on the analysis of findings involving the above three questions, a few recommendations for further research are suggested.

This is a qualitative meta-analysis of studies, influenced by interpretations of existing theories and models (Collins \& Fauser, 2005; also see, Luckner, 2017). Qualitative meta-analysis is a rigorous narrative analysis of primary and secondary research findings and can be undertaken by a multi-disciplinary team (Greenhalgh, Potts, Wong, \& Bark, Swinglehurst, 2009).The various approaches to this type of research have engendered a variety of labels such as qualitative meta-analysis, meta-synthesis, meta-data analysis, meta-ethnography, meta-study, meta-summary, meta-method, metatheory, and grounded formal theory (Timulak, 2007). For the present study, this analysis should extend the knowledge base on inclusion for $\mathrm{d} / \mathrm{Dhh}$ children and adolescents. To the best of our knowledge, this is a seminal study utilizing this type of analysis on the above research questions.

\section{METHOD}

\section{Search Procedures}

We reviewed and analyzed the literature in three stages. First, several electronic search engines were used, including Education Full Text (Wilson), ERIC, EBSCOhost, ProQuest, and PsycInfo, to obtain relevant articles. In addition, selected individual journals with published research on d/Dhh children such as American Annals of the Deaf, Deafness \& Education International, the Journal of Deaf Studies \& Deaf Education, and the Volta Review were perused. Specific key phrases and words included inclusion of deaf and hard of hearing students, academic achievement of deaf students in general education classroom, full inclusion, social inclusion, interaction of deaf students in general education classroom, access to the general education curriculum, and the challenges of including deaf and hard of hearing students. Second, after selecting studies from the above search engines, the reference list of each study was reviewed to locate additional sources. Third, all selected articles were reviewed, and articles that did not meet the inclusion criteria were excluded. 
The criteria for including studies in this meta-analysis were as follows:

1. Because there are few studies that have examined the inclusion of $\mathrm{d} / \mathrm{Dhh}$ students, studies conducted between 1985 and 2017, inclusive, were selected. The debate and research on inclusion emerged during the late 1980s (e.g., Paul \& Ward, 1996; Winzer, 2009).

2. Due to the dearth of primary empirical studies, two broad types of research were considered; primary empirical investigations and secondary research reviews.

3. Participants should be, at least, students who were $\mathrm{d} /$ Deaf and hard of hearing or teachers of $\mathrm{d} /$ Deaf and hard of hearing students.
4. Articles were reviewed if the issues concern the inclusion of students who were $\mathrm{d} /$ Deaf and hard of hearing in general-education classrooms.

\section{ANALYSIS}

The systematic search of databases and journals yielded 23 studies that met the inclusion criteria. Each selected article was analyzed with respect to providing information pertaining to one or more of the research questions listed above. Below are summaries of the research articles, presented in a Table format.

Table 1. Summary of the Reviewed Studies

\begin{tabular}{|c|c|c|c|c|c|}
\hline Author \& Date & Country & $\begin{array}{l}\text { Research } \\
\text { purpose }\end{array}$ & Methods & Participants & Findings \\
\hline $\begin{array}{l}\text { Afzali-Nomani } \\
\text { (1995) }\end{array}$ & $\begin{array}{l}\text { USA } \\
\text { (Kansas) }\end{array}$ & $\begin{array}{l}\text { To investigate the } \\
\text { effects of full inclu- } \\
\text { sion on the academ- } \\
\text { ic achievement and } \\
\text { social development } \\
\text { of D/HH and hear- } \\
\text { ing children. }\end{array}$ & $\begin{array}{l}\text { The researcher used } \\
\text { a non-experimental } \\
\text { research design. Spe- } \\
\text { cifically, a multiple } \\
\text { regression analysis } \\
\text { was performed to } \\
\text { optimally combine } \\
\text { scores on the five edu- } \\
\text { cational conditions } \\
\text { scales to enhance pre- } \\
\text { diction of each of the } \\
\text { six criteria. }\end{array}$ & $\begin{array}{l}55 \text { teachers of } \mathrm{d} / \\
\text { Dhh students and } \\
\text { general educa- } \\
\text { tion teachers who } \\
\text { were employed } \\
\text { in public school } \\
\text { districts. These } \\
\text { teachers should } \\
\text { have experiences } \\
\text { teaching in full in- } \\
\text { clusion programs. }\end{array}$ & $\begin{array}{l}\text { The teachers were asked to rate } \\
\text { the effects of inclusion on d/Dhh } \\
\text { students based on three criteria: } \\
\text { academic achievement, social } \\
\text { adjustment, and self-confidence/ } \\
\text { esteem. Findings show that in- } \\
\text { clusion has a positive impact on } \\
\text { the academic achievement of stu- } \\
\text { dents with hearing loss. However, } \\
\text { the positive effects of inclusion } \\
\text { on d/Dhh students increase when } \\
\text { students receive social encour- } \\
\text { agement, when teachers support } \\
\text { the program, and when there is a } \\
\text { full range of placement options. }\end{array}$ \\
\hline $\begin{array}{l}\text { Angelides and } \\
\text { Aravi (2006) }\end{array}$ & Cyprus & $\begin{array}{l}\text { To investigate the } \\
\text { experiences of } \mathrm{d} / \\
\text { Dhh students in in- } \\
\text { clusive education } \\
\text { schools and in spe- } \\
\text { cial schools. }\end{array}$ & $\begin{array}{l}\text { The study followed an } \\
\text { interpretive model of } \\
\text { research based on the } \\
\text { three basic premises } \\
\text { of symbolic interac- } \\
\text { tionism:1) human be- } \\
\text { ings act toward things } \\
\text { on the basis of the } \\
\text { meanings the things } \\
\text { have for them, 2) the } \\
\text { meanings of such } \\
\text { things derive from, or } \\
\text { arise out of, the social } \\
\text { interaction that one } \\
\text { has with one's fellows, } \\
3 \text { ) these meanings are } \\
\text { handled in, and modi- } \\
\text { fied through, an inter- } \\
\text { pretative process used } \\
\text { by the person. }\end{array}$ & $\begin{array}{l}20 \text { individu- } \\
\text { als with hearing } \\
\text { loss that ranged } \\
\text { from mild to pro- } \\
\text { found in inclusive } \\
\text { schools and in } \\
\text { special schools. }\end{array}$ & $\begin{array}{l}\text { The researchers investigated the } \\
\text { experiences of } 20 \mathrm{~d} / \mathrm{Dhh} \text { students } \\
\text { in inclusive schools and in spe- } \\
\text { cial schools. Deaf and hard of } \\
\text { hearing participants reported that } \\
\text { the inclusive schools provided } \\
\text { more opportunities for learning } \\
\text { than special schools. Also, the } \\
\text { researchers asserted that includ- } \\
\text { ing d/Dhh students in inclusive } \\
\text { classrooms obliged teachers to } \\
\text { differentiate their instruction to } \\
\text { meet students' needs. Further, } \\
\text { the inclusion of d/Dhh students } \\
\text { led teachers to develop collabo- } \\
\text { rations between themselves in } \\
\text { order to facilitate the learning of } \\
\text { not only d/Dhh students, but also } \\
\text { of all children. Finally, the inclu- } \\
\text { sion of d/Dhh students led teach- } \\
\text { ers to the development of more } \\
\text { inclusive practices, which influ- } \\
\text { ence all students in the school. }\end{array}$ \\
\hline
\end{tabular}




\begin{tabular}{|c|c|c|c|c|c|}
\hline Author \& Date & Country & $\begin{array}{c}\text { Research } \\
\text { purpose }\end{array}$ & Methods & Participants & Findings \\
\hline $\begin{array}{l}\text { Antia, Jones, } \\
\text { Luckner, } \\
\text { Kreimeyer, and } \\
\text { Reed (2011) }\end{array}$ & $\begin{array}{l}\text { USA } \\
\text { (Arizona } \\
\text { and } \\
\text { Colorado) }\end{array}$ & $\begin{array}{l}\text { To examine the } \\
\text { social skills and } \\
\text { problem behav- } \\
\text { iors of d/Dhh } \\
\text { students who } \\
\text { attended gen- } \\
\text { eral education } \\
\text { classrooms. }\end{array}$ & $\begin{array}{l}\text { The researchers } \\
\text { used a non-exper- } \\
\text { imental research } \\
\text { design. Specifically, } \\
\text { the researcher used } \\
\text { descriptive analysis } \\
\text { to describe the so- } \\
\text { cial interaction. }\end{array}$ & $\begin{array}{l}191 \text { students with } \\
\text { mild to profound } \\
\text { hearing loss who at- } \\
\text { tended general edu- } \\
\text { cation classrooms } \\
\text { for } 2 \text { or more hours } \\
\text { per day. }\end{array}$ & $\begin{array}{l}\text { The results showed that the average } \\
\text { change over } 5 \text { years in social skills } \\
\text { and problem behaviors of d/Dhh } \\
\text { students was not significant. The } \\
\text { most consistent predictors of social } \\
\text { outcomes for d/Dhh students were } \\
\text { the students' classroom communi- } \\
\text { cation and participation in extracur- } \\
\text { ricular activities. }\end{array}$ \\
\hline $\begin{array}{l}\text { Antia, Jones, } \\
\text { Reed, and } \\
\text { Kreimeyer } \\
\text { (2009) }\end{array}$ & $\begin{array}{l}\text { USA } \\
\text { (Arizona } \\
\text { and } \\
\text { Colorado) }\end{array}$ & $\begin{array}{l}\text { To examine } \\
\text { the academic } \\
\text { achievement of } \\
\text { d/Dhh students } \\
\text { who attend gen- } \\
\text { eral education } \\
\text { classrooms. }\end{array}$ & $\begin{array}{l}\text { Non-experimental } \\
\text { research design us- } \\
\text { ing a teacher rating } \\
\text { scale-the Academic } \\
\text { Competence Scale } \\
\text { of the Social Skills } \\
\text { Rating System. Also, } \\
\text { the researchers used } \\
\text { both normative and } \\
\text { classroom academic } \\
\text { data to determine the } \\
\text { academic progress of } \\
\text { d/Dhh students. }\end{array}$ & $\begin{array}{l}197 \text { students with } \\
\text { mild to profound } \\
\text { hearing loss who at- } \\
\text { tended general edu- } \\
\text { cation classrooms } \\
\text { for } 2 \text { or more hours } \\
\text { per day. }\end{array}$ & $\begin{array}{l}\text { The scores of } \mathrm{d} / \text { Dhh students on } \\
\text { standardized achievement tests } \\
\text { indicated that, those students' } \\
\text { academic achievement was in the } \\
\text { average or above-average range in } \\
\text { math and reading. }\end{array}$ \\
\hline $\begin{array}{l}\text { Antia, } \\
\text { Kreimeyer, and } \\
\text { Eldredge (1994) }\end{array}$ & $\begin{array}{l}\text { ASU } \\
\text { (Arizona, } \\
\text { California, } \\
\text { Oregon, } \\
\text { Washing- } \\
\text { ton State, } \\
\text { Pennsylva- } \\
\text { nia, and the } \\
\text { District of } \\
\text { Columbia) }\end{array}$ & $\begin{array}{l}\text { To examine the } \\
\text { effects of two } \\
\text { social skills in- } \\
\text { tervention con- } \\
\text { ducted by Antia } \\
\text { and Kreimeyer } \\
(1987,1988) \text { on } \\
\text { the peer social } \\
\text { interactions. }\end{array}$ & $\begin{array}{l}\text { The researchers } \\
\text { adapted the social } \\
\text { skills intervention } \\
\text { for d/hh children in } \\
\text { segregated preschool } \\
\text { programs for use in } \\
\text { inclusive situations } \\
\text { by providing oppor- } \\
\text { tunities for children } \\
\text { without hearing loss } \\
\text { to learn sign lan- } \\
\text { guage during the in- } \\
\text { tervention sessions, } \\
\text { if necessary. }\end{array}$ & $\begin{array}{l}105 \text { young children } \\
\text { with and without } \\
\text { hearing loss from } \\
13 \text { different pre- } \\
\text { schools, kindergar- } \\
\text { ten, and 1st-grade } \\
\text { programs. }\end{array}$ & $\begin{array}{l}\text { The interactions between students } \\
\text { with hearing loss and typical hear- } \\
\text { ing students were increased after } \\
\text { the intervention was implement- } \\
\text { ed. The results showed that using } \\
\text { long-term interventions within } \\
\text { small, stable groups of children } \\
\text { with and without hearing loss is } \\
\text { effective. }\end{array}$ \\
\hline $\begin{array}{l}\text { Batten, Oakes, } \\
\text { and Alexander } \\
(2014)\end{array}$ & N/A & $\begin{array}{l}\text { To investi- } \\
\text { gate whether } \\
\text { teachers had } \\
\text { the attitudes, } \\
\text { know ledge, } \\
\text { and teaching } \\
\text { skills proposed } \\
\text { to support the } \\
\text { effective inclu- } \\
\text { sion of students } \\
\text { in regular class- } \\
\text { rooms. }\end{array}$ & $\begin{array}{l}\text { A systematic litera- } \\
\text { ture review using a } \\
\text { wide range of elec- } \\
\text { tronic databases. }\end{array}$ & $\begin{array}{l}\text { The researchers re- } \\
\text { viewed and analyzed } \\
14 \text { qualitative, quan- } \\
\text { titative, or mixedde- } \\
\text { sign studies with par- } \\
\text { ticipants aged 4-19 } \\
\text { years old with hear- } \\
\text { ing loss. Specifically, } \\
\text { seven of these stud- } \\
\text { ies included d/Dhh } \\
\text { children aged from } 4 \\
\text { to } 12 \text {, whereas three } \\
\text { studies included d/ } \\
\text { Dhh children aged } \\
\text { from } 12 \text { to } 19 \text {. Also, } \\
\text { eight studies includ- } \\
\text { ed participants with } \\
\text { cochlear implants, } \\
\text { with one study in- } \\
\text { cluding bilateral } \\
\text { cochlear implants. }\end{array}$ & $\begin{array}{l}\text { The researchers conducted a sys- } \\
\text { tematic literature review to ex- } \\
\text { plore factors associated with so- } \\
\text { cial interaction between d/Dhh } \\
\text { children and hearing peers. The } \\
\text { study found that child's age, com- } \\
\text { municational competency, and } \\
\text { level of mainstreaming was posi- } \\
\text { tively associated with peer inter- } \\
\text { actions. }\end{array}$ \\
\hline
\end{tabular}


Continuation of table 1.

\begin{tabular}{|c|c|c|c|c|c|}
\hline Author \& Date & Country & $\begin{array}{c}\text { Research } \\
\text { purpose }\end{array}$ & Methods & Participants & Findings \\
\hline $\begin{array}{l}\text { Eriks-Brophy \& } \\
\text { Whittingham, } \\
\text { (2013) }\end{array}$ & $\begin{array}{l}\text { Ottawa, } \\
\text { Canada }\end{array}$ & $\begin{array}{l}\text { To examine } \\
\text { teachers' at- } \\
\text { titudes toward } \\
\text { the inclusion of } \\
\text { d/Deaf and hard } \\
\text { of hearing stu- } \\
\text { dents. }\end{array}$ & $\begin{array}{l}\text { Non-experimental } \\
\text { research design, us- } \\
\text { ing survey research. }\end{array}$ & $\begin{array}{l}\text { The participants in- } \\
\text { cluded } 63 \text { teachers } \\
\text { in general education } \\
\text { classrooms. }\end{array}$ & $\begin{array}{l}\text { The researchers found that teaching } \\
\text { experience and having family mem- } \\
\text { bers with a disability most affected } \\
\text { the attitudes of these teachers. The } \\
\text { participants also indicated that their } \\
\text { teacher education programs had in- } \\
\text { sufficiently prepared them to teach } \\
\text { these students effectively. }\end{array}$ \\
\hline Holt (1994) & USA & $\begin{array}{l}\text { To investigate } \\
\text { reading com- } \\
\text { prehension and } \\
\text { mathematics } \\
\text { computation } \\
\text { achievement of } \\
\text { d/Dhh students } \\
\text { in a variety of } \\
\text { school settings. }\end{array}$ & $\begin{array}{l}\text { Data were collected } \\
\text { by Gallaudet Uni- } \\
\text { versity Center for } \\
\text { Assessment and } \\
\text { Demographic Stud- } \\
\text { ies during its } 1990 \\
\text { standardization of } \\
\text { the 8th Edition Stan- } \\
\text { ford Achievement } \\
\text { Test. The researchers } \\
\text { used descriptive and } \\
\text { inferential methods } \\
\text { to analyze the re- } \\
\text { lationships among } \\
\text { achievement scores. }\end{array}$ & $\begin{array}{l}\text { A sample of d/Dhh } \\
\text { students, ages } 6 \\
\text { through } 21, \text { selected } \\
\text { for a project that } \\
\text { produced special } \\
\text { norms for the Stan- } \\
\text { ford Achievement } \\
\text { Test, 8th Edition } \\
\text { (SAT8). }\end{array}$ & $\begin{array}{l}\text { The results indicated that the } \\
\text { scores on reading comprehen- } \\
\text { sion and mathematic of d/Dhh } \\
\text { students who are educated with } \\
\text { hearing students in general educa- } \\
\text { tion classroom were higher than } \\
\text { in segregated settings. However, it } \\
\text { was not known whether the higher } \\
\text { achievement is due to inclusion } \\
\text { or whether students were selected } \\
\text { for inclusion due to their higher } \\
\text { achievement levels. }\end{array}$ \\
\hline $\begin{array}{l}\text { Hung and Paul } \\
\text { (2006) }\end{array}$ & \begin{tabular}{|l|} 
USA \\
(Ohio)
\end{tabular} & $\begin{array}{l}\text { To examine } \\
\text { whether the in- } \\
\text { clusion of d/ } \\
\text { Dhh students af- } \\
\text { fects attitudes of } \\
\text { typical hearing } \\
\text { students. Specifi- } \\
\text { cally, it explored } \\
\text { the effects of fac- } \\
\text { tors such as con- } \\
\text { tact experience, } \\
\text { closeness, class } \\
\text { norms, and de- } \\
\text { mographical in- } \\
\text { formation (class } \\
\text { setting, grade } \\
\text { level, and gen- } \\
\text { der) on typical } \\
\text { hearing students' } \\
\text { attitudes toward } \\
\text { inclusion of d/ } \\
\text { Dhh students in } \\
\text { general educa- } \\
\text { tion classrooms. }\end{array}$ & $\begin{array}{l}\text { This study utilized a } \\
\text { correlational research } \\
\text { design, entailing a } \\
\text { survey approach with } \\
\text { direct group adminis- } \\
\text { tration to collect data. }\end{array}$ & $\begin{array}{l}\text { Students with and } \\
\text { without hearing loss } \\
\text { in general education } \\
\text { classroom in middle } \\
\text { and high schools. }\end{array}$ & $\begin{array}{l}\text { The findings revealed that includ- } \\
\text { ing d/Dhh students in general } \\
\text { education classrooms increases } \\
\text { contact between d/Dhh students } \\
\text { and typical hearing students. This } \\
\text { effective contact between students } \\
\text { is a significant reason that typical } \\
\text { hearing students have positive at- } \\
\text { titudes toward students with hear- } \\
\text { ing loss. }\end{array}$ \\
\hline
\end{tabular}




\begin{tabular}{|c|c|c|c|c|c|}
\hline Author \& Date & Country & $\begin{array}{l}\text { Research } \\
\text { purpose }\end{array}$ & Methods & Participants & Findings \\
\hline $\begin{array}{l}\text { Johnson and } \\
\text { Johnson (2012) }\end{array}$ & USA & $\begin{array}{l}\text { To compare co- } \\
\text { operative and } \\
\text { individualistic } \\
\text { learning experi- } \\
\text { ences between } \\
\text { hearing students } \\
\text { and students } \\
\text { with hearing loss } \\
\text { and their effects } \\
\text { on interactions } \\
\text { and relationships } \\
\text { between the stu- } \\
\text { dents. }\end{array}$ & $\begin{array}{l}\text { The researcher used } \\
\text { an experimental de- } \\
\text { sign to compare the } \\
\text { two groups of stu- } \\
\text { dents. }\end{array}$ & $\begin{array}{l}10 \mathrm{~d} / \text { Dhh students } \\
\text { in 3rd-grade and } \\
20 \text { hearing students } \\
\text { were the partici- } \\
\text { pants. }\end{array}$ & $\begin{array}{l}\text { The results showed that students } \\
\text { involved in cooperative learning } \\
\text { experiences performed higher on } \\
\text { measures of interactions and inter- } \\
\text { personal attractions between typical } \\
\text { hearing and d/Dhh students than did } \\
\text { students involved in individualistic } \\
\text { learning experiences. }\end{array}$ \\
\hline Kluwin (1993) & USA & $\begin{array}{l}\text { To examine the } \\
\text { effects of in- } \\
\text { clusion on the } \\
\text { achievement } \\
\text { and grade point } \\
\text { average (GPA) } \\
\text { of d/Dhh stu- } \\
\text { dents. }\end{array}$ & $\begin{array}{l}\text { The research used a } \\
\text { comparison design, } \\
\text { and data was col- } \\
\text { lected via the Annu- } \\
\text { al Survey Data and } \\
\text { Annual Survey of } \\
\text { Hearing Impaired } \\
\text { Children and Youth. }\end{array}$ & $\begin{array}{l}451 \text { students, with } \\
\text { hearing loss, range } \\
\text { from mild to pro- } \\
\text { found, from } 15 \text { pub- } \\
\text { lic school programs. }\end{array}$ & $\begin{array}{l}\text { The results showed that inclusive } \\
\text { education for d/Dhh students has } \\
\text { a positive effect on their academic } \\
\text { achievement. Specifically, d/Dhh } \\
\text { students who attended general } \\
\text { education classrooms have higher } \\
\text { scores on the achievement tests. } \\
\text { The researcher concluded that in- } \\
\text { cluding students with hearing loss } \\
\text { in general education classrooms is } \\
\text { important to engage these students } \\
\text { in a high-quality academic atmos- } \\
\text { phere. }\end{array}$ \\
\hline $\begin{array}{l}\text { Kluwin and } \\
\text { Moores (1989) }\end{array}$ & USA & $\begin{array}{l}\text { To examine } \\
\text { the mathemat- } \\
\text { ics achieve- } \\
\text { ment of } \mathrm{d} / \mathrm{Dhh} \\
\text { adolescents in } \\
\text { mainstream and } \\
\text { self-contained } \\
\text { classrooms. }\end{array}$ & $\begin{array}{l}\text { Descriptive re- } \\
\text { search design, using } \\
\text { a survey to collect } \\
\text { data. }\end{array}$ & $\begin{array}{l}215 \mathrm{~d} / \text { Dhh students } \\
\text { with an average age } \\
\text { of } 16.7 \text { years and } 63 \\
\text { teachers. }\end{array}$ & $\begin{array}{l}\text { The results indicated that d/Dhh } \\
\text { students' background factors have } \\
\text { a significant impact on their math- } \\
\text { ematics achievement. Also, it was } \\
\text { found that interpreters have no } \\
\text { specific effect on mathematics } \\
\text { achievement of d/Dhh students in } \\
\text { mainstream classrooms. Finally, } \\
\text { the results showed that the quality } \\
\text { of instruction is the prime deter- } \\
\text { minant of achievement, regardless } \\
\text { of placement. }\end{array}$ \\
\hline $\begin{array}{l}\text { Kluwin and } \\
\text { Moores (1985) }\end{array}$ & USA & $\begin{array}{l}\text { To examine the } \\
\text { relative effects } \\
\text { of placement } \\
\text { in an integrated } \\
\text { class on the } \\
\text { mathematics } \\
\text { achievement of } \\
\text { d/Dhh adoles- } \\
\text { cents. }\end{array}$ & $\begin{array}{l}\text { Comparison re- } \\
\text { search design with } \\
\text { a questionnaire to } \\
\text { collect data was } \\
\text { used. }\end{array}$ & $\begin{array}{l}36 \mathrm{~d} / \text { Dhh students } \\
\text { in mainstream } \\
\text { mathematics classes } \\
\text { were compared with } \\
44 \mathrm{~d} / \text { Dhh students } \\
\text { in self-contained } \\
\text { classrooms. All } \\
\text { students in main- } \\
\text { stream mathemat- } \\
\text { ics and self-con- } \\
\text { tained classes were } \\
\text { matched on mathe- } \\
\text { matics ability, read- } \\
\text { ing ability, degree } \\
\text { of hearing loss, and } \\
\text { social adjustment. }\end{array}$ & $\begin{array}{l}\text { The results showed that } \mathrm{d} / \mathrm{Dhh} \\
\text { students in inclusive classrooms } \\
\text { performed significantly better than } \\
\text { the students in the self-contained } \\
\text { classes. Further, the results identi- } \\
\text { fied four factors, including higher } \\
\text { expectations, exposure to greater } \\
\text { quantities of demanding material, } \\
\text { availability of individual support, } \\
\text { and training in academic content } \\
\text { for regular mathematics teachers, } \\
\text { for the differences in mathematics } \\
\text { achievement between students in } \\
\text { inclusive classroom and those in } \\
\text { self-contained classes. }\end{array}$ \\
\hline
\end{tabular}


Continuation of table 1.

\begin{tabular}{|c|c|c|c|c|c|}
\hline Author \& Date & Country & $\begin{array}{l}\text { Research } \\
\text { purpose }\end{array}$ & Methods & Participants & Findings \\
\hline Leigh (1999) & USA & $\begin{array}{l}\text { To examine the } \\
\text { effects of inclu- } \\
\text { sion on the per- } \\
\text { sonal develop- } \\
\text { ment of d/Dhh } \\
\text { students. }\end{array}$ & $\begin{array}{l}\text { Descriptive re- } \\
\text { search design was } \\
\text { used. Data were } \\
\text { collected, using a } \\
\text { 12- item open-end- } \\
\text { ed questionnaire. }\end{array}$ & $\begin{array}{l}34 \text { d/Dhh adults, } \\
\text { who typically de- } \\
\text { pend on speech as } \\
\text { the preferred com- } \\
\text { munication method, } \\
\text { at the Oral Hearing- } \\
\text { Impaired Section } \\
\text { (OHIS) of the Alex- } \\
\text { ander Graham Bell } \\
\text { Association. }\end{array}$ & $\begin{array}{l}\text { Participants emphasized that their } \\
\text { educational experiences contrib- } \\
\text { uted to the change in their percep- } \\
\text { tion about themselves. Further, half } \\
\text { of the participants indicated they } \\
\text { changed their self-labels because } \\
\text { their perceptions of the personal def- } \\
\text { inition of hearing loss had changed. }\end{array}$ \\
\hline $\begin{array}{l}\text { Marschark, } \\
\text { Shaver, Nagle, } \\
\text { \& Newman } \\
(2015)\end{array}$ & USA & $\begin{array}{l}\text { To investigate } \\
\text { the effects of } \\
\text { factors, includ- } \\
\text { ing the charac- } \\
\text { teristics of d/ } \\
\text { Dhh students, } \\
\text { the character- } \\
\text { istics of their } \\
\text { family environ- } \\
\text { ments, and their } \\
\text { experiences, on } \\
\text { the academic } \\
\text { achievement of } \\
\text { d/Dhh students } \\
\text { in secondary } \\
\text { schools. }\end{array}$ & $\begin{array}{l}\text { The researchers } \\
\text { analyzed data from } \\
\text { the National Lon- } \\
\text { gitudinal Transition } \\
\text { Study-2 (NLTS2), } \\
\text { funded by the U.S. } \\
\text { Department of Edu- } \\
\text { cation in 2000. Spe- } \\
\text { cifically, they used } \\
\text { cross-wave, cross- } \\
\text { instrument weight } \\
\text { appropriate for multi- } \\
\text { ple waves of NLTS2 } \\
\text { data and multiple } \\
\text { instruments to ac- } \\
\text { commodate for de- } \\
\text { sign effects and the } \\
\text { complex nature of } \\
\text { the data set. }\end{array}$ & $\begin{array}{l}500 \mathrm{~d} / \text { Dhh who } \\
\text { received their edu- } \\
\text { cation in regular } \\
\text { secondary school } \\
\text { or state-sponsored } \\
\text { special schools de- } \\
\text { signed for d/Dhh } \\
\text { students. }\end{array}$ & $\begin{array}{l}\text { The findings indicated a signifi- } \\
\text { cant relationship between the in- } \\
\text { dependent variables, including } \\
\text { having an additional diagnosis of } \\
\text { a learning disability, having a mild } \\
\text { hearing loss, being African Amer- } \\
\text { ican or Hispanic, and the depend- } \\
\text { ent variable-academic achieve- } \\
\text { ment of d/Dhh students. }\end{array}$ \\
\hline $\begin{array}{l}\text { McCain and } \\
\text { Antia (2005) }\end{array}$ & USA & $\begin{array}{l}\text { To examine the } \\
\text { communication } \\
\text { participation, ac- } \\
\text { ademic achieve- } \\
\text { ment, and so- } \\
\text { cial behavior } \\
\text { of five d/Dhh } \\
\text { students, five d/ } \\
\text { Dhh students } \\
\text { with additional } \\
\text { disabilities, and } \\
18 \text { nondisabled, } \\
\text { typical hearing } \\
\text { peers in a co- } \\
\text { enrolled, Grade } \\
\text { 3-4-5 combina- } \\
\text { tion classroom. }\end{array}$ & $\begin{array}{l}\text { The research- } \\
\text { ers used a mixed- } \\
\text { model Analysis of } \\
\text { Variance (ANOVA) } \\
\text { with the four CPQ } \\
\text { scores as the repeat- } \\
\text { ed measure and the } \\
\text { three groups as the } \\
\text { between-subjects } \\
\text { measure to analyze } \\
\text { data. }\end{array}$ & $\begin{array}{l}5 \mathrm{~d} / \text { Dhh students, } 5 \\
\mathrm{~d} / \text { Dhh students with } \\
\text { additional disabili- } \\
\text { ties, and } 18 \text { non- } \\
\text { disabled, hearing } \\
\text { peers. }\end{array}$ & $\begin{array}{l}\text { The findings indicated that } \mathrm{d} / \mathrm{Dhh} \\
\text { students were not significantly } \\
\text { different from their typical hear- } \\
\text { ing peers in communication par- } \\
\text { ticipation and social behavior. The } \\
\text { researchers found differences in } \\
\text { academic achievement, but } \mathrm{d} / \mathrm{Dhh} \\
\text { students made steady academic pro- } \\
\text { gress over } 3 \text { years. Also, the findings } \\
\text { showed that d/Dhh students with ad- } \\
\text { ditional disabilities were significant- } \\
\text { ly different from their typical hearing } \\
\text { peers, but not from their d/Dhh peers } \\
\text { in all areas. Finally, the researchers } \\
\text { concluded that co-enrollment is a } \\
\text { possible beneficial model of inclu- } \\
\text { sion for d/Dhh students. }\end{array}$ \\
\hline $\begin{array}{l}\text { Musselman \& } \\
\text { Mootilal (1997) }\end{array}$ & Canada & $\begin{array}{l}\text { To examine the } \\
\text { social adjust- } \\
\text { ment of d/Dhh } \\
\text { adolescents en- } \\
\text { rolled in segre- } \\
\text { gated, partially } \\
\text { integrated, and } \\
\text { mainstream set- } \\
\text { tings. }\end{array}$ & $\begin{array}{|lr|}\text { Comparison re- re } & \text { rearch design with } \\
\text { serar } & \text { questionnaire to } \\
\text { collect data was } \\
\text { used. }\end{array}$ & $\begin{array}{l}39 \mathrm{~d} / \text { Dhh adoles- } \\
\text { cents enrolled in } \\
\text { segregated settings, } \\
15 \text { deaf adolescents } \\
\text { in partially inte- } \\
\text { grated settings, } 17 \\
\text { deaf adolescents } \\
\text { in mainstream set- } \\
\text { tings, and } 88 \text { typical } \\
\text { hearing students. }\end{array}$ & $\begin{array}{l}\mathrm{d} / \text { Dhh students in segregated class- } \\
\text { rooms exhibited the lowest levels of } \\
\text { adjustment overall. Also, partially } \\
\text { integrated students exhibited better } \\
\text { adjustment than mainstream stu- } \\
\text { dents with deaf peers; mainstream } \\
\text { students reported better adjustment } \\
\text { than did partially integrated students } \\
\text { with typical hearing peers, exhibit- } \\
\text { ing the same levels of adjustment as } \\
\text { those of typical hearing peers. }\end{array}$ \\
\hline
\end{tabular}


Continuation of table 1.

\begin{tabular}{|c|c|c|c|c|c|}
\hline Author \& Date & Country & $\begin{array}{c}\text { Research } \\
\text { purpose }\end{array}$ & Methods & Participants & Findings \\
\hline Powers (2003) & England & $\begin{array}{l}\text { To investigate } \\
\text { student and fam- } \\
\text { ily factors that } \\
\text { affect academic } \\
\text { achievements of } \\
\text { d/Dhh children. }\end{array}$ & $\begin{array}{l}\text { The researcher used } \\
\text { a survey to collect } \\
\text { data. For data anal- } \\
\text { ysis, the researcher } \\
\text { used inferential and } \\
\text { descriptive meth- } \\
\text { ods. }\end{array}$ & $\begin{array}{l}82 \mathrm{~d} / \text { Dhh students } \\
\text { who were educat- } \\
\text { ed in mainstream } \\
\text { schools. }\end{array}$ & $\begin{array}{l}\text { The findings showed the complex- } \\
\text { ity of interpreting statistical results, } \\
\text { especially on the effects of degree of } \\
\text { hearing loss. }\end{array}$ \\
\hline $\begin{array}{l}\text { Reed, Antia, } \\
\text { and Kreimeyer } \\
(2008)\end{array}$ & $\begin{array}{l}\text { USA } \\
\text { (Arizona } \\
\text { and } \\
\text { Colorado) }\end{array}$ & $\begin{array}{l}\text { To examine the } \\
\text { variables that } \\
\text { affect the aca- } \\
\text { demic success } \\
\text { of d/Dhh stu- } \\
\text { dents in general } \\
\text { education class- } \\
\text { rooms. }\end{array}$ & $\begin{array}{l}\text { The researchers } \\
\text { used a qualitative } \\
\text { research design, } \\
\text { and data were col- } \\
\text { lected as part of a } \\
\text { large longitudinal } \\
\text { study of academic } \\
\text { and social progress } \\
\text { of d/Dhh students } \\
\text { in general educa- } \\
\text { tion classrooms. }\end{array}$ & $\begin{array}{l}25 \text { students with } \\
\text { mild to profound } \\
\text { hearing loss who at- } \\
\text { tended general edu- } \\
\text { cation classrooms. }\end{array}$ & $\begin{array}{l}\text { The results indicated that the aca- } \\
\text { demic achievement of d/Dhh stu- } \\
\text { dents is influenced by factors such } \\
\text { as student self-advocacy and mo- } \\
\text { tivation, high family and school } \\
\text { expectations, families' ability to } \\
\text { help with homework, and good } \\
\text { communication between profes- } \\
\text { sionals. }\end{array}$ \\
\hline $\begin{array}{l}\text { Richardson, } \\
\text { Marschark, } \\
\text { Sarchet, and } \\
\text { Sapere (2010) }\end{array}$ & USA & $\begin{array}{l}\text { To investigate } \\
\text { the experiences } \\
\text { of d/Dhh stu- } \\
\text { dents in general } \\
\text { education class- } \\
\text { rooms versus in } \\
\text { separate educa- } \\
\text { tion classrooms. }\end{array}$ & $\begin{array}{l}\text { The researchers } \\
\text { used two surveys } \\
\text { to collect data. Data } \\
\text { were analyzed by } \\
\text { using chi square } \\
\text { tests and logistic } \\
\text { regression analysis. }\end{array}$ & $\begin{array}{l}217 \mathrm{~d} / \mathrm{Dhh} \text { stu- } \\
\text { dents who studied } \\
\text { at Rochester Insti- } \\
\text { tute of Technology } \\
\text { (RIT). }\end{array}$ & $\begin{array}{l}\text { Findings indicated that students } \\
\text { in separate classrooms prefer to } \\
\text { communicate with typical hear- } \\
\text { ing students using sign, speech } \\
\text { and sign, or notes. Also, those } \\
\text { students reported that they prefer } \\
\text { to use sign or speech and sign to } \\
\text { communicate with teachers in } \\
\text { mainstream classes. On the other } \\
\text { side, students in inclusive educa- } \\
\text { tion classrooms prefer to use an } \\
\text { interpreter or speech to communi- } \\
\text { cate with typical hearing students } \\
\text { as well as their teachers. }\end{array}$ \\
\hline $\begin{array}{l}\text { Stinson and Liu } \\
\text { (1999) }\end{array}$ & USA & $\begin{array}{l}\text { To identify the } \\
\text { key issues con- } \\
\text { cerning partici- } \\
\text { pation of d/Dhh } \\
\text { students in gen- } \\
\text { eral education } \\
\text { classrooms. }\end{array}$ & $\begin{array}{l}\text { This study used } \\
\text { a qualitative ap- } \\
\text { proach to collect } \\
\text { data and report the } \\
\text { results. }\end{array}$ & $\begin{array}{l}40 \text { teachers of } \mathrm{d} / \\
\text { Dhh students and } \\
\text { educational inter- } \\
\text { preters. }\end{array}$ & $\begin{array}{l}\text { The researchers reported that } \\
\text { there are many factors that influ- } \\
\text { ence d/Dhh student's participation } \\
\text { in general education classrooms, } \\
\text { including their degree of hearing } \\
\text { loss, teachers' attitudes, and teach- } \\
\text { ers' abilities to engage students in } \\
\text { their lessons. }\end{array}$ \\
\hline $\begin{array}{l}\text { Wauters and } \\
\text { Knoors (2008) }\end{array}$ & Netherlands & $\begin{array}{l}\text { To examine so- } \\
\text { cial integration } \\
\text { of d/Dhh chil- } \\
\text { dren in inclu- } \\
\text { sive settings. }\end{array}$ & $\begin{array}{l}\text { A structural equa- } \\
\text { tion modeling was } \\
\text { used. The research- } \\
\text { ers used two instru- } \\
\text { ments to measure } \\
\text { peer relations in the } \\
\text { various classrooms: } \\
\text { peer ratings and } \\
\text { peer nominations. }\end{array}$ & $\begin{array}{l}18 \mathrm{~d} / \text { Dhh students } \\
(56 \% \text { female, } 44 \% \\
\text { male) and } 344 \text { hear- } \\
\text { ing students }(52 \% \\
\text { female, } 48 \% \text { male }) \\
\text { in Grade } 1-5 \text { partic- } \\
\text { ipated in the study. }\end{array}$ & $\begin{array}{l}\text { The findings showed that } \mathrm{d} / \mathrm{Dhh} \\
\text { children were similar in their peer } \\
\text { acceptance and friendship relations, } \\
\text { but there were differences in social } \\
\text { competence. Specifically, d/Dhh } \\
\text { children scored lower than typical } \\
\text { hearing children on prosocial behav- } \\
\text { ior and higher on socially withdrawn } \\
\text { behavior. In addition, the structural } \\
\text { equation modeling showed peer ac- } \\
\text { ceptance, social competence, and } \\
\text { friendship relations to be stable over } \\
\text { time, and the structure of interre- } \\
\text { lations between variables on two } \\
\text { measurements were found to be the } \\
\text { same for d/Dhh and typical hearing } \\
\text { participants. }\end{array}$ \\
\hline
\end{tabular}


Continuation of table 1.

\begin{tabular}{|l|l|l|l|l|l|}
\hline Author \& Date & \multicolumn{1}{|c|}{ Country } & \multicolumn{1}{c|}{$\begin{array}{c}\text { Research } \\
\text { purpose }\end{array}$} & Methods & Participants & \multicolumn{1}{c|}{ Findings } \\
\hline $\begin{array}{l}\text { Xie, Potmešil, } \\
\text { and Peters } \\
(2014)\end{array}$ & N/A & $\begin{array}{l}\text { To describe how } \\
\text { d/Dhh children } \\
\text { interact with } \\
\text { hearing peers in } \\
\text { inclusive educa- } \\
\text { tion classrooms. }\end{array}$ & $\begin{array}{l}\text { A systematic litera- } \\
\text { ture review using a } \\
\text { tronic databases. }\end{array}$ & $\begin{array}{l}21 \text { studies were re- } \\
\text { viewed and analyzed. }\end{array}$ & $\begin{array}{l}\text { The study found that d/Dhh stu- } \\
\text { dents faced challenges in com- } \\
\text { municating, initiating/entering, } \\
\text { and maintaining interactions with } \\
\text { typical hearing peers in inclusive } \\
\text { education classrooms. Also, these } \\
\text { students needed effective inter- } \\
\text { ventions to assist them to continue } \\
\text { in the general education class- } \\
\text { rooms. }\end{array}$ \\
\hline
\end{tabular}

\section{RESULTS}

The results of the meta-analysis are reported for each research question.

\section{1) What are the prominent perspectives on the ef- fects of inclusion for $\mathrm{d} / \mathrm{Dhh}$ students?}

The literature review reveals much controversy on the inclusive education of $\mathrm{d} / \mathrm{Dhh}$ students. Several researchers (Angelides \& Aravi, 2006; Innes, 1994; Powers, 2003) indicated that there is ongoing debate over whether $d / D h h$ students should be considered differently from the situation of other students with disabilities. In other words, the unique language and communication needs of $\mathrm{d} / \mathrm{Dhh}$ students may pose challenges that are different from those of students with other types of disabilities (e.g., Xie, Potmesil, \& Peters, 2014). d/Dhh students often experience difficulties in understanding instructions and other information from teachers. Particularly, some students with hearing loss may not understand up to $25 \%$ of the verbal classroom instructions and interactions. Hung (2005; also see, Hung \& Paul, 2006) also cited researchers who argued that the best educational setting for $\mathrm{d} / \mathrm{Dhh}$ students is one in which a signed language is used solely or in conjunction with a spoken language (e.g., signed system). These researchers believe that a number of $\mathrm{d} / \mathrm{Dhh}$ students experience difficulty in general education classrooms because these students prefer an educational setting that represents the d/Deaf community with an emphasis on Deaf culture and signed language. Thus, including these $\mathrm{d} /$ Dhh children in general education classrooms may negatively influence their peer relationships and their academic achievement.

On the other hand, a number of researchers believe that there is no essential need for a special education classroom (and curriculum) for $\mathrm{d} / \mathrm{Dhh}$ students because they can succeed academically and socially in general education classrooms with typical (hearing) peers (Afzali-Nomani, 1995; Antia, Jones, Reed, \& Kreimeyer, 2009; Johnson \& Johnson, 2012; Kluwin, 1993). This argument is supported by the basic tenet of the qualitative similarity hypothesis (QSH), which asserts that the learning trajectory of $\mathrm{d} / \mathrm{Dhh}$ students is developmental similar to that of typical (hearing) students (Paul, Wang, \& Williams, 2013). The QSH asserts that the knowledge acquisition process of $\mathrm{d} / \mathrm{Dhh}$ students is qualitatively similar to that of typical learners with the only exception being that the knowledge acquisition rate of some $d / D h h$ students might be delayed or slower. Accordingly, the slower knowledge acquisition rate of $\mathrm{d} / \mathrm{Dhh}$ students, particularly language and literacy development, can be addressed by using instructional and curriculum accommodations and modifications such as Visual Phonics, Cued Speech, and other strategies that have a visual component.

In the reviewed articles, we found a range of perspectives regarding the effects of inclusion on the academic achievement of $\mathrm{d} / \mathrm{Dhh}$ students. In general, the academic achievement of $\mathrm{d} / \mathrm{Dhh}$ students was measured through the use of standardized test scores or was based on teachers' perceptions (Antia, Jones, Reed, \& Kreimeyer, 2009; McCain \& Antia, 2005). Some researchers reported that the academic achievement of $d / D h h$ students was lower than that of typical hearing students. For example, Holt (1994) reported that $\mathrm{d} / \mathrm{Dhh}$ students in general education schools performed lower than typical hearing students in reading comprehension and mathematics problem solving.

From another perspective, a number of studies reported that $\mathrm{d} / \mathrm{Dhh}$ students who are educated in general education classrooms have a higher academic achievement than those who receive their education in special education (i.e., self-contained) classrooms (Afzali-Nomani, 1995; Kluwin, 1993). 
Other researchers have also reported a positive effect of inclusion on the academic achievement of $\mathrm{d} / \mathrm{Dhh}$ students (Afzali-Nomani, 1995; Angelides \& Aravi, 2006; Antia, Jones, Reed, \& Kreimeyer, 2009; Holt, 1994; Kluwin, 1993; McCain \& Antia, 2005). Among the latter group of researchers, there is a consensus that inclusive education provides $\mathrm{d} / \mathrm{Dhh}$ students with specific high academic goals, entails an effective use of assessments, and presents a rich curriculum, which assists in developing the necessary abilities and skills for academic achievement.

Antia et al. (2009) investigated the academic achievement of 197 students with mild to profound hearing loss who attended a general education classroom for two or more hours per day. The results indicated that the majority of these students scored in the average or above-average range on standardized mathematics, reading, language, and writing achievement tests. Anita et al. also indicated that teachers rated $69-81 \%$ of the $\mathrm{d} / \mathrm{Dhh}$ students in the general education classrooms as average or above average in academic achievement.

Angelides and Aravi (2006) examined the experiences of $20 \mathrm{~d} / \mathrm{Dhh}$ students in inclusive schools and in special schools (i.e., schools for children with specific disabilities). The researchers found that inclusive schools provided more opportunities for learning than special schools did, and that students in inclusive schools received richer and more thorough instruction than did the students in special schools. Furthermore, the researchers asserted that including $\mathrm{d} / \mathrm{Dhh}$ students in inclusive classrooms obliged teachers to differentiate their instruction to meet students' needs as well as to develop collaborations between themselves to facilitate the learning of not only $\mathrm{d} / \mathrm{Dhh}$ students, but also of all the students. The researchers concluded that the inclusion of $\mathrm{d} / \mathrm{Dhh}$ students led teachers to the development of more effective inclusive practices, which influence all students in the school.

Another issue that has diverse perspectives is the social integration of $\mathrm{d} /$ Dhh students in general education classrooms (Antia et al., 2011; Hung, 2005; Hung \& Paul, 2006; Musselman \& Mootilal, 1997; Wauters \& Knoors, 2008). Although the literature on social interactions of $\mathrm{d} / \mathrm{Dhh}$ students is limited and results are inconsistent (Xie, Potmesil, \& Peters, 2014), some researchers indicated that $\mathrm{d} / \mathrm{Dhh}$ students in general education classrooms tend to face social barriers in terms of making friends and participating in social activities (Antia, Kreimeyer \& Eldredge, 1994; Antia \& Stinson, 1999; Batten, Oakes \& Alexander, 2014; Stinson \& Liu, 1999; Xie, Potmesil, \& Peters, 2014).
These researchers attributed the social problems of $\mathrm{d} /$ Dhh students in general education classrooms to difficulties with their language and communication abilities. Specifically, the researchers asserted that these social problems might vary based on students' degree of hearing loss. For example, students with severe to profound hearing loss may experience more isolation and loneliness in general education classrooms than students who have less severe levels of hearing loss (i.e., hard of hearing). These researchers also asserted that the negative attitudes of teachers and peers in general education classrooms toward $\mathrm{d} / \mathrm{Dhh}$ students can be a significant reason for social interaction challenges and can limit classroom participation of $\mathrm{d} / \mathrm{Dhh}$ students. It is reiterated that $\mathrm{d} / \mathrm{Dhh}$ students' proficiency level of spoken language and communication skills is the most common factor leading to the harboring of negative attitudes among teachers and typical hearing peers (Hung \& Paul, 2006).

Antia and Stinson (1999) admitted also that there are social challenges that $\mathrm{d} / \mathrm{Dhh}$ students face in general education classrooms; however, these researchers asserted that inclusion eliminates the deleterious effects of isolation and the stigma attached to $\mathrm{d} / \mathrm{Dhh}$ students. Other researchers (Antia, Kreimeyer, \& Eldredge, 1994; Batten, Oakes, \& Alexander, 2014; McCain \& Antia, 2005; Wauters \& Knoors, 2008) also emphasized that not all $\mathrm{d} / \mathrm{Dhh}$ students experience isolation and rejection in inclusive classrooms. They believe that inclusion has a positive impact on $\mathrm{d} / \mathrm{Dhh}$ students by increasing their access to the typical linguistic and behavioral models of their typical hearing peers. Furthermore, Leigh (1999) argued that inclusion plays an important role in increasing $\mathrm{d} / \mathrm{Dhh}$ students' self-confidence and in changing their negative self-perceptions. In essence, the above investigators maintained that it is important for teachers and school staff to create effective contexts where $\mathrm{d} / \mathrm{Dhh}$ students can frequently interact with typical hearing peers. In other words, the role of teachers in inclusive education classrooms is not only to improve d/Dhh students' academic outcomes, but also to increase their social interactions via classroom social activities.

\section{2) Are the research findings on the effects of inclu- sion of $d / D h h$ students consistent or inconsistent?}

Our review of the research on the inclusion of $\mathrm{d} / \mathrm{Dhh}$ students in general education classrooms revealed few inconsistent findings that may be the result of the use of different research methodologies or different measurements and tests (Antia, Jones, Reed, \& Kreimeye, 2009). 
Another major reason for the inconsistent findings is due to the d/Dhh students' diverse experiences and to differences in the home and school environments. A few researchers (Kluwin \& Moores, 1989; Marschark, Shaver, Nagle, \& Newman, 2015; Powers, 2003; Reed, Antia, \& Kreimeyer, 2008; Richardson, Marschark, Sarchet, \& Sapere, 2010) emphasized that there is tremendous variation in $\mathrm{d} / \mathrm{Dhh}$ children with respect to, for example, degree of hearing loss, factors associated with their home environment (e.g., parental involvement; language and literacy experiences), school context (e.g., teacher competency; teacher and students' attitudes), and their language and communication skills. d/Deaf and hard of hearing children come from different racial, ethnic, and economic backgrounds, and there are other significant factors that can impact findings such as early identification of hearing loss, early intervention services, consistent use of amplification, and familyoriented infant programming (Antia, Jones, Reed, \& Kreimeye, 2009; Powers, 2003; Wang \& Engler, 2011). Diversity among d/Dhh children also affects their education and achievement in general education classrooms as well as their communication and interaction with teachers and typical hearing peers (Marschark, Shaver, Nagle, \& Newman, 2015; Xie, Potmešil, \& Peters, 2014). Thus, conducting research on the inclusion of $\mathrm{d} / \mathrm{Dhh}$ students requires an understanding of students' individual characteristics, demography, and home and cultural backgrounds to be able to report reliable and valid findings. For example, some studies did not distinguish between students with severe and profound hearing loss and those with less severe hearing (Afzali-Nomani, 1995; Marschark, Shaver, Nagle, \& Newman, 2015; Powers, 2003). This difference in degree of hearing loss may have a significant effect on each student's academic achievement and social interaction in general education classrooms. This difference also affects the generalization of findings and the proffering of valid implications.

In addition to factors discussed above, our review revealed that a school's context raises significant factors that contribute to the inconsistent results about the inclusion of d/Dhh students (Antia, Jones, Reed, \& Kreimeye, 2009). For example, d/Dhh students who received their education from highly qualified teachers and in motivated learning environments often exhibited better academic achievement and social interaction than $\mathrm{d} / \mathrm{Dhh}$ students in other educational settings (Marschark, Shaver, Nagle, \& Newman,
2015). Students who were educated in schools that provided them with a variety of learning activities for acquiring and improving language skills and developing their learning readiness from kindergarten to third grade and further also showed better academic achievement and social interaction than $\mathrm{d} / \mathrm{Dhh}$ students in other educational settings (Marschark, Shaver, Nagle, \& Newman, 2015). In essence, researchers must consider the influences that a school's context has on $\mathrm{d} / \mathrm{Dhh}$ students who are participants in their studies. More specifically, researchers must gather sufficient information about each school's learning environment in terms of possible academic and emotional support such as tutoring, effective instruction, and effective social interactions.

\section{3) What are the suggestions to enhance the inclu- sion of $\mathrm{d} / \mathrm{Dhh}$ students?}

Our review indicated that a number of $\mathrm{d} / \mathrm{Dhh}$ students can succeed academically and socially in general education classrooms with typical hearing peers (Afzali-Nomani, 1995; Angelides \& Aravi, 2006; Holt, 1994; Kluwin, 1993; Marschark, Shaver, Nagle, \& Newman, 2015; Powers, 2003). d/Deaf and hard of hearing students can gain access to general education curriculum when they receive effective and appropriate educational supports and services from staff in schools, in particular, teachers (Antia, Jones, Reed, \& Kreimeyer, 2009; Powers, 2003). There is no need to develop special curricula for students; the focus should be on increasing the rate of students' knowledge through differentiation of instruction with the general education curriculum. As mentioned previously, to increase the English literacy acquisition rate for a number of $\mathrm{d} / \mathrm{Dhh}$ students, researchers have suggested using techniques such as Visual Phonics and Cued Speech, to assist with accessing phonology and other phonological processes, an important component of early literacy development (Paul et al., 2013; Wang, Trezek, Luckner, \& Paul, 2008).

Other researchers pointed out the importance of providing support services to $\mathrm{d} / \mathrm{Dhh}$ students in general education classrooms to assist them in gaining access to the general education curriculum (Afzali-Nomani, 1995; Antia et al., 2011). These researchers indicated that educational interpreting (sign and oral interpreters) is an important support service for $\mathrm{d} / \mathrm{Dhh}$ students in general education classrooms to facilitate communication with their teachers and classroom peers. Berndsen and Luckner (2012) emphasized the importance of the use of technology. 
In other words, the inclusive classroom teachers must have sufficient training in how to use educational technology (e.g., smartboards, Internet, etc.). In addition, these researchers argued that general education classrooms should be equipped with adequate educational technologies and materials to facilitate the roles of teachers in these settings.

Our review revealed that the successful inclusion of $\mathrm{d} / \mathrm{Dhh}$ students in general education classrooms relates to a number of significant factors; however-as mentioned previously-facilitating and improving the language and communication skills of $\mathrm{d} / \mathrm{Dhh}$ students is also critical for successful inclusion. For example, Hung (2005; also see Antia, Jones, Luckner, Kreimeyer, \& Reed, 2011; Batten, Oakes, \& Alexander, 2014; Hung \& Paul, 2006; Johnson \& Johnson, 2012) emphasized that facilitating the communication and contact between $\mathrm{d} / \mathrm{Dhh}$ students and typical hearing peers is a significant reason that typical students develop positive attitudes toward d/Dhh students. Similarly, Batten, Oakes, and Alexander (2014) indicated that inclusion of $\mathrm{d} / \mathrm{Dhh}$ students cannot be successfully achieved without considering and addressing $\mathrm{d} /$ Dhh children's experiences, including their language skills. In essence, improving the language and literacy skills of $\mathrm{d} / \mathrm{Dhh}$ students is not only important for improving their communication with teachers and peers, but also, it provides $\mathrm{d} / \mathrm{Dhh}$ students with the ability to access the general education curriculum and to participate effectively in assessment programs. The reviewed articles (Antia, Jones, Luckner, Kreimeyer, \& Reed, 2011; Antia, Kreimeyer, \& Eldredge, 1994; Batten, Oakes, \& Alexander, 2014; Hung \& Paul, 2006; Musselman \& Mootilal, 1997) suggested other important factors-several mentioned previously-that are necessary for $\mathrm{d} / \mathrm{Dhh}$ students to succeed in general education classrooms. These factors include family involvement, self-determination, extracurricular activities, friendships, social skills, self-advocacy skills, collaboration with early identification and early intervention service providers, high expectations, and preteach/teach/postteach content and vocabulary being learned in the general education classrooms. Several articles that were reviewed (Afzali-Nomani, 1995; Antia, Jones, Reed, \& Kreimeyer, 2009; Cochran-Smith, 2003; Luckner \& Muir, 2002; Marschark, Shaver, Nagle, \& Newman, 2015) agreed that the inclusive education of $d / \mathrm{Dhh}$ students cannot succeed unless teachers fulfill their role by effectively participating and collaborating in the inclusion process while providing high-quality instruction. The researchers emphasized that high- quality instruction is necessary for improving student learning in terms of understanding how, what, and why they learn. For example, Power (2002) indicated teachers must understand the practice of inclusion so that they utilize effective instructional strategies in the general education classroom. This implies that it is not sufficient for inclusive classroom teachers to have knowledge-based content alone to teach students successfully, but they must also understand inclusive practice and methods to communicate and interact with students.

Research on the proficiency and attitudes of teachers in general and special education also revealed critical findings for effective inclusive practices, especially for $\mathrm{d} / \mathrm{Dhh}$ children and adolescents. For example, some researchers (Afzali-Nomani, 1995; Eriks-Brophy, \& Whittingham, 2013) indicated that special education teachers, including teachers of d/Dhh students had sufficient knowledge about the educational practice of inclusion and of the characteristics of students, but they lacked the necessary knowledge and skills to teach content areas such as mathematics, science, and reading. Special education teachers demonstrated better understanding of inclusive education practice and were better at motivating students with disabilities than were general education teachers. These researchers also pointed out that special education teachers exhibited more confidence than did general education teachers in working and collaborating with the parents of children with disabilities. On the other hand, most general education teachers had a good grasp of knowledge-based-content, but they lacked sufficient knowledge about the needs of students with disabilities and of inclusive education practices such as collaborative team-teaching skills and working as a part of an Individual Education plan (IEP) team.

A number of articles, which were not analyzed in this study, also found that general education teachers did not have the skills needed to appropriately and effectively adapt instruction to meet the needs of students with disabilities in general education classrooms. For example, Scruggs and Mastropieri (1996) reported that one third, at most, of general education teachers believed that they had sufficient training, skills, and resources necessary to teach in an inclusive classroom. According to the teachers in this study, their lack of knowledge about the practice of inclusion and of the characteristics of students with disabilities had a pervasive effect on their perceptions and degree of acceptance about including students with disabilities in their classrooms. 
This study indicated that general education teachers need more training in the methodology of teaching students with disabilities, implementing collaboration, and using different sources in developing instruction materials. The researchers also argued that general education teachers need more training than did special education teachers in areas such as assessing academic progress, adapting curriculum, developing IEPs, and using assistive technology.

\section{RECOMMENDATIONS FOR FUTURE RE- SEARCH}

Given the range of factors that needs to be considered, doing inclusive research on children and adolescents who are $\mathrm{d} / \mathrm{Dhh}$ and on other populations is challenging and controversial (e.g., Allan \& Slee, 2008). This assertion can even be gleaned from current textbooks for preparing teachers to work in inclusive classrooms (e.g., Bryant, Bryant, \& Smith, 2017). In one sense, research on inclusive education is similar to conducting research on the effectiveness of teacher-education programs for which there is a number of impactful factors. Variables of interest for inclusive education research entail, at least, those associated with the environment (e.g., school, classroom, home), the teacher (e.g., proficiency, attitudes, teacher-student interaction, co-teaching), curriculum (e.g., accessibility), and the student (e.g., demography; factors associated with language, cognition, and the affective domain). Understanding the effects of inclusion on a macro level using group/quantitative research designs cannot be accomplished with one or two investigations. Conducting research on the macro level, including group intervention research, is even more challenging for low-incidence populations such as children and adolescents who are d/Deaf and hard of hearing. If macro-level research is desirable, especially for comparison purposes (e.g., inclusive versus segregated environments), then we recommend that, as much as possible, researchers document adequate information related to demography (e.g., hearing loss, age at onset, amplification usage, etc.) and achievement (e.g., language and communication levels). The documentation of these variable, at least, is critical for proffering evidence-based practices (Council for Exceptional Children, 2014). It is impossible to document or statistically control all factors, as mentioned above, related to inclusive practices. Nevertheless, given our growing understanding of the complexity of inclusion, it is clear that there will be limitations to macro-level research investigations that need to be highlighted. Recognizing these limitations might diminish the inconsistencies and misinterpretations of findings. We believe that large-scale experimental intervention studies as well as observational, nonexperimental investigations might continue to be challenging and rare-albeit we recognize that this is a major approach for evaluating the effectiveness of inclusive programs on a macro level.

There are certainly other types of research designs such as single-case, qualitative, and those associated with action research that can be utilized to evaluate effectiveness for an individual or a small group, who are part of a low-incidence population. These designs, including those associated with research in disability studies seem to be focused on addressing barriers that impede the successful inclusion of individuals in general education classrooms (e.g., Allan \& Slee, 2008; Valle \& Conner, 2011). In essence, this line of research is not focused on the evaluation of inclusive practices per se; rather, it is motivated by the question: What can be done to create a successful inclusive environment for this particular individual?

\section{LIMITATIONS}

Every study has limitations, and the present one is no exception. The validity of a qualitative meta-analysis is dependent on the quality of the selection of studies under review and the accuracy of the interpretations of the present researchers. The focus of this meta-analysis was on the reported findings of primary empirical studies and the balanced interpretations of findings provided by the authors of secondary research reviews.

The meta-analysis of secondary research reviews or of other meta-analyses can pose specific challenges because of the dependence on the reporting of findings based on the quality of studies that were reviewed (e.g., Xie, Potmesil, \& Peters, 2014). That is, the interpretations provided in the present study are dependent on the quality indicators or technical merits of investigations that were analyzed by other researchers who conducted the secondary reviews. There are additional caveats to consider when interpreting studies that have utilized surveys (e.g., EriksBrophy \& Whittingham, 2013; Hung \& Paul, 2006; Kluwin, 1993; Powers, 2003). Even with procedures to minimize error, it should be remembered that the survey responses in studies are based on the individual subjective perceptions of participants. 
Similar concerns can be raised for investigations that employ the use of self-reports (e.g., Afzali-Nomani, 1995).

The discussion of the above limitations does not diminish the reliability and validity of the investigations that were analyzed. Nevertheless, the conclusions of the present study should be viewed with caution. More important, it is hoped that the present study influences other researchers to conduct similar or additional meta-analyses.

\section{CONCLUSION}

It is critical to conduct evidence-based research to understand the effects of inclusion on individuals who are $d /$ Deaf and hard of hearing. As discussed in this article, research on the effects of inclusive education practices requires the consideration of a number of factors and entails the use of different, and often complex, research designs. Future researchers need to be aware of the diversity of demographics in $\mathrm{d} / \mathrm{Dhh}$ children and adolescents, and the strengths and limitations of assessments, research designs, and teacher practices. Awareness of these quality indicators (or technical merits) and others should minimize the generalization of findings to dissimilar populations of $\mathrm{d} /$ Dhh individuals and should enhance the proffering of effective educational implications.

The manner in which inclusion of $\mathrm{d} / \mathrm{Dhh}$ children and adolescents should be investigated can become extremely political and may impede our growing understanding of this complex construct if we are not considerate of a variety of perspectives. Nevertheless, as noted by Allan and Slee (2008):

Inclusive education is a political imperative and questions of who gets an education and the character of that education compared with others cannot be construed as apolitical. Closing down the discussion or maintaining the barricades in order to feel more confident about one's dogma is not constructive. The technical and political need not always be antithetical. We would argue that an open and respectful conversation about ideology, choices and the impact of these choices on the subjects and products of the research is timely (p. 99).

\section{REFERENCES}

\section{Note: Articles that are asterisked (*) have been re- viewed in the present study.}

*Afzali-Nomani, E. (1995). Educational conditions related to successful full inclusion programs involving deaf/hard of hearing children. American Annals of the Deaf, 140(5), 396-401.

Allan, J., \& Slee, R. (2008). Doing inclusive education research. Rotterdam, the Netherlands: Sense Publishers.

*Angelides, P., \& Aravi, C. (2006).A comparative perspective on the experiences of deaf and hard of hearing individuals as students at mainstream and special schools. American Annals of the Deaf, 151(5), 476-487.

Angelides, P., \& Aravi, C. (2007). The development of inclusive practices as a result of the process of integrating deaf-hard of hearing students. European Journal of Special Needs Education, 22(1), 63-74.

*Antia, S. D., Jones, P. B., Reed, S., \& Kreimeyer, K. H. (2009). Academic status and progress of deaf and hard-of-hearing students in general education classrooms. Journal of Deaf Studies \& Deaf Education, 14(3), 293-311. doi:10.1093/ deafed/enp009

*Antia, S. D., Jones, P., Luckner, J., Kreimeyer, K. H., \& Reed, S. (2011). Social outcomes of students who are deaf and hard of hearing in general education classrooms. Exceptional Children, 77(4), 489-504.

*Antia, S. \& Kreimeyer, K., Eldredge N. (1994). Promoting social interaction between young children with impaired hearing and their hearing peers. A comparison of a social skills intervention and an integrated activities intervention. Exceptional Children, 60(3), 262-275.

Antia S. D, Stinson M. S. (1999). Some conclusions on the education of deaf and hard-of-hearingstudents in inclusive settings. Journal of Deaf Studies and Deaf Education, 4(3), 246-248.doi:10.1093/deafed/4.3.246.

*Batten, G., Oakes, P. M., \& Alexander, T. (2014). Factors associated with social interactions between deaf children and their hearing peers: A systematic literature review. Journal of Deaf Studies \& Deaf Education, 19(3), 285-302.

Berndsen, M., \& Luckner, J. (2012). Supporting students who are deaf or hard of hearing in general education classrooms: A Washington state case study. Communication Disorders Quarterly, 33(2), 111-118.

Bryant, D., Bryant, B. R., \& Smith, D. D. (2017). Teaching students with special needs in inclusive classrooms. Thousand Oaks, CA: Corwin.

Cochran-Smith, M. (2003). Learning and unlearning: the education of teacher educators. Teaching and Teacher Education, 19(1), 5-28.

Consortium for Research in Deaf Education (2017). CRIDE report on 2016/17 survey on educational provision for deaf children in England. Nottingham, England.The Ear Foundation Limited.

Collins, J. A., \& Fauser, B. C. J. M. (2005). Balancing the strengths of systematic and narrative reviews. Human Reproduction Update, 11(2), 103-104. 
Council for Exceptional Children. (2014). Council for Exceptional Children standards for evidence-based practices in special education. Exceptional Children, 80, 504-511. doi:10.1177/0014402914531388.

Easterbrooks, S. R. (2017). Conceptualization, development, and application of research in deaf education: From phenomenon to implementation. In S. W. Cawthon \& C. L. Garberoglio (Eds.), Research in deaf education: Contexts, challenges, and considerations (pp. 1-34). New York, NY: Oxford University Press.

Eatough, M. (2000). Raw data from the BATOD Survey England January 1998. British Association of Teachers of the Deaf Magazine, May, 1-8.

Eriks-Brophy, A., \& Whittingham, J. (2013). Teachers' perceptions of the inclusion of children with hearing loss in general education settings. American Annals of the Deaf, 158(1), 63-97.

Greenhalgh T, Potts H.W., Wong G., \& Bark, P., Swinglehurst, D. (2009). Tensions and paradoxes in electronic patient record research: A systematic literature review using the meta-narrative method. Milbank Quarterly, 87(4), 729-788.

*Holt, J. (1994). Classroom attributes and achievement test scores for deaf and hard of hearing students. American Annals of the Deaf, 139(4), 430-37.

Hung, H. (2005). Factors associated with the attitudes of nondisabled secondary school students toward the inclusion of peers who are deaf or hard of hearing in their general education classes. (Electronic Thesis or Dissertation). Retrieved from https://etd-ohiolink-edu.proxy.lib.ohio-state. edu/.

*Hung, H.-L., \& Paul, P. V. (2006). Inclusion of students who are deaf or hard of hearing: secondary school hearing students' perspectives. Deafness \& Education International, 8(2), $62-74$.

Innes, J. J. (1994). Full inclusion and the deaf student: A deaf consumer's review of the issue. American Annals of the Deaf, 139(2), 152-156.

Johnson, H. A. (2013). Initial and ongoing teacher preparation and support: Current problems and possible solutions. American Annals of the Deaf, 157(5), 439-449.

Johnson, H. A. (2004). U.S. deaf education teacher preparation programs: A look at the present and a vision for the future. American Annals Of The Deaf, 149(2), 75-91.

*Johnson, D. W., \& Johnson, R. T. (2012). Mainstreaming hearing-impaired students: The effect of effort in communicating on cooperation and interpersonal attraction. The Journal of Psychology, 119(1), 31-44.

*Kluwin, T. N. (1993). Cumulative effects of mainstreaming on the achievement of deaf adolescents. Exceptional Children, 60(1), 73-81.

*Kluwin,T. N., \& Moores D. F. (1989). Mathematics achievement of hearing impaired adolescents in different placements. Exceptional Children, 55(4), 327-335.

*Kluwin,T. N., \& Moores D. F.(1985). The effects of integration on the mathematics achievement of hearing impaired adolescents. Exceptional Children, 52(2), 153-160.

*Leigh, I. (1999). Inclusive education and personal development. Journal of Deaf Studies and Deaf Education, 4(3), 236245.
Luckner, J. L. (2017). Research synthesis. In S. W. Cawthon \& C. L. Garberoglio (Eds.), Research in deaf education: Contexts, challenges, and considerations (pp. 325-340). New York, NY: Oxford University Press.

Luckner, J. \& Muir, S. (2002). Suggestions for helping students who are deaf succeed in general education settings. Communication Disorders Quarterly, 24(1), 23-30.

*Marschark, M., Shaver, D. M., Nagle, K. M., \& Newman, L. A. (2015). Predicting the academic achievement of deaf and hard-of-hearing students from individual, household, communication, and educational factors. Exceptional Children, 81(3), 350-369.

*McCain, K. G., \& Antia, S. D. (2005). Academic and social status of hearing, deaf, and hard of hearing students participating in a co-enrolled classroom. Communication Disorders Quarterly, 27(1), 20-32.

Mitchell, R. E. (2017). Demographics for deaf education. In S. W. Cawthon \& C. L. Garberoglio (Eds.), Research in deaf education: Contexts, challenges, and considerations (pp. 93-119). New York, NY: Oxford University Press.

*Musselman, C., \& Mootilal, A. (1997).The social adjustment of deaf adolescents in segregated, partially integrated, and mainstreamed settings. Journal of Deaf Studies and Deaf Education, 1(1), 52-63.

Paul, P. V., \& Wang, Y. (2017). Publishing in refereed journals: Unpacking a few salient reporting standards. In S. W. Cawthon \& C. L. Garberoglio (Eds.), Research in deaf education: Contexts, challenges, and considerations (pp. 341-360). New York, NY: Oxford University Press.

Paul, P., Wang, Y., \& Williams, C. (2013). Deaf students and the qualitative similarity hypothesis: Understanding language and literacy development. Washington DC: Gallaudet University Press.

Paul, P. V., \& Ward, M. E. (1996). Inclusion paradigms in conflict. Theory into Practice, 35(1), 4-11.

*Powers, S. (2003). Influences of student and family factors on academic outcomes of mainstream secondary school deaf students. Journal of Deaf Studies and Deaf Education, 8(1), 57-78.

Powers, S. (2002). From concepts to practice in deaf education: A United Kingdom perspective on inclusion. Journal of Deaf Studies \& Deaf Education, 7(3), 230-243.

*Reed, S., Antia, S. D., \& Kreimeyer, K. H. (2008). Academic status of deaf and hard-of-hearing students in public schools: student, home, and service facilitators and detractors. Journal of Deaf Studies and Deaf Education, 13(4), 485-502.

*Richardson, J.T.E., Marschark, M., Sarchet, T., \& Sapere, P. (2010). Deaf and hard-of-hearing students' experiences in mainstream and separate postsecondary education. Journal of Deaf Studies and Deaf Education, 15(4), 358-382.

Salend, S. (2001). Creating inclusive classrooms: Effective and reflective practices (4th ed.). Columbus, $\mathrm{OH}$ : Merrill Prentice Hall.

Scruggs, T. E., \& Mastropieri, M. A. (1996). Teacher perceptions of mainstreaming/inclusion, 1958-1995: A research synthesis. Exceptional Children, 63(1), 59-74.

Standley, L.(2005).Sociolinguistic perspectives on the education of deaf children in inclusion placements. In J. Cohen, K. T. McAlister, K. Rolstad, \& J. MacSwan (Eds.), Proceedings of the 4th International Symposium on Bilingualism (pp. 2180-2188). Somerville, MA: Cascadilla Press 
*Stinson, M.S., \& Liu, Y. (1999). Participation of deaf and hard of hearing students in classes with hearing students. Journal of Deaf Studies and Deaf Education, 4(3),191-202.

Timulak, L. (2007). Identifying core categories of client identified impact of helpful events in psychotherapy: A qualitative meta-analysis. Psychotherapy Research, 17, 305-314.

U.S. Department of Education (2013). 35th Annual Report to Congress on the Implementation of the Individuals with Disabilities Education Act. Washington, D.C: U.S. Department of Education.

Valle, J. W., \& Conner, D J. (2011). Rethinking disability: A disability studies approach to inclusive practices. New York, NY: McGraw-Hill.

Wang, Y., \& Engler, K. (2011). Early intervention. In P. Paul \& G. Whitelaw, Hearing and deafness (pp. 241-268). Sudbury, MA: Jones \& Bartlett.
Wang, Y., Trezek, B., Luckner, J., \& Paul, P. (2008). The role of phonology and phonological related skills in reading instruction for students who are deaf or hard of hearing. American Annals of the Deaf, 153(4), 396-407.

*Wauters, L. N., \& Knoors, H. (2008). Social integration of deaf children in inclusive settings. Journal of Deaf Studies and Deaf Education, 13(1), 21-36.

Winzer, M. A. (2009). From integration to inclusion: A history of special education in the $20^{\text {th }}$ century. Washington, DC: Gallaudet University Press

*Xie, Y.-H., Potmesil, M., \& Peters, B. (2014). Children who are deaf or hard of hearing in inclusive educational settings: A literature review on interactions with peers. Journal of Deaf Studies and Deaf Education, 19(4), 423-437. 